\title{
ARTICLES \\ Nineteenth-Century Collectors of Ukrainian Folk Legends: Their Views, Objectives, Methods and Their Informants
}

\author{
Roman I. Shiyan \\ University of Alberta, Canadian Institute of Ukrainian Studies
}

In this article I shall attempt to answer the following questions: 1) is it possible to reconstruct the views and objectives of the first collectors of folk legends about the Ukrainian Cossacks as well as to recreate their "method?," and if the answer is yes, then to what extent?; 2) How do the personal attitudes of collectors of folklore and their informants affect the folklore texts? This article features an abridged and modified version of a discussion, presented in my doctoral dissertation "Cossack motifs in Ukrainian folk legends."(1)

The article mainly focuses on Panteleimon Kulish, Iakiv Novyts'ky and Dmytro Iavornyts'ky, whose views, methods and contributions can be established with a considerable degree of certainty. Panteleimon Kulish (1819-1897) was a prominent Ukrainian writer, historian, ethnographer and folklorist. Born into a family with Cossack antecedents, Kulish grew up in an atmosphere of respect for folk tradition. In the 1840s, while a student at Kyiv University, Kulish began collecting folklore. In 1845, he published the first chapters of his novel Chorna rada (The rebels' council), so establishing himself as a writer. A year later, he published his first historical work, Povest' ob ukrainskom narode (The story of the Ukrainian people) [Doroshenko 1996: 110-11]. He subsequently taught literature at theUniversity of St Petersburg. In 1847, Kulish conducted more ethnographic and folklore research in the "western provinces of the Russian empire," or in other words, in Ukraine.

Fascinated by the Ukrainian past, Kulish was particularly interested in the Ukrainian Cossacks. His view of them varied considerably over time, ranging from fascination to disapproval, and eventually to harsh criticism. He began his historical studies by delving into the Cossack chronicles as well as folk poetry and prose glorifying the Cossacks. However, Kulish's later acquaintance with certain archival documents and works by Polish authors made him critical of the Cossacks. Kulish condemned their frequent squabbles, their shifts in loyalty and their unruliness, thus blaming the Cossacks for their "destructive role" in the 
quest for Ukrainian statehood. The first signs of his negative stance towards the Cossacks were evident even in Chorna Rada, which was first published as a whole in 1857. His historical works of the 1870s, especially Materialy dlia istorii vossoedineniia Ukrainy $s$ Rossiei (Sources for the history of the unification of Ukraine with Russia) (187778), were markedly anti-Cossack in tone [Doroshenko 1923: 171-81].

The folklore material garnered by Panteleimon Kulish during his expeditions in the 1840s was published in 1855-56 as Zapiski o Iuzhnoi Rusi (Notes on Southern Rus'). In this work Kulish included folk tales, songs, dumy (2) and legends that related to both pre-Cossack and Cossack times. Legends represented only one area of his interests, though an important one. They were collected in what is now central Ukraine, primarily in the Kyiv and Poltava regions. Kulish recorded legends about the origin of the Cossacks, the initiation of a novice prior to his acceptance into the Cossack brotherhood, reminiscences about Cossack ways and customs, Cossack chastity, their fancy appearance, their trickery, and life at Cossack fishing enterprises, as well as legends about certain Cossack individuals, such as the Zaporozhian Cossack Vasiurynsky, Hetman Bohdan Khmelnyts'ky, Khmelnyts'ky's son Yurii, Colonel Semen Palii and Hetman Ivan Mazepa.

Zapiski provides some insight into Kulish's approaches to and his philosophy as a folklorist. In the "Introduction" he indicates that, like many of his contemporaries, he has "... always been fascinated by stories told by the common people" [Kulish 1856: 1]. As his own testimony shows, it took Kulish some time to realize the importance of taking notes during the actual performance:

I long ago began to value those stories; however, for a long time I was mistaken, considering that [my] memory alone is sufficient for their preservation. My experience proved to me that memory retains only the spirit and the contents of the story, but the original form of the stories gives way to general forms of everyday speech...finally, I became convinced that I should not rely upon memory, but record every unique pattern of speech in the story and every transition from one thought to another [Kulish: 1].

Kulish made observations about the relationship between informants and the events they described which may be considered groundbreaking for the time. In his opinion, the number of intermediaries involved in passing on a particular story did affect its content. On one occasion the collector noted that he was told two very similar stories about brigands hiding in the reeds (komyshnyky). One of the informants, Iurchenko, told his story as an "echo"- a very vague memory of an actual event, passed on to him via several intermediaries. In contrast, another interviewee, Klym Belik, actually knew the participants of the 
particular event he narrated (his father and his father's friend), and his account thus represented a re-telling of a first-person experience [Kulish: 159].

In his work, Panteleimon Kulish often demonstrates what can be called "educated skepticism," mostly questioning the reliability of some of his informants and their stories from the standpoint of a historian. On one occasion he writes, "I do not completely trust the account of Kindrat Taranukha" about the Cossack company commander Kharko [Kulish: 98]. To Kulish, the "fantasies" of his informants undermined the credibility of certain accounts. For instance, while presenting a narrative about the Tsar leaving his will engraved on a stone, in which he forbade the taking of lands from the Cossacks, Kulish indicated his view that the content of the inscription had been made up:

It would be curious to find out what guided Vasyl' Kutsenko, while he was reading a non-existent inscription on that stone. The narrator's father traveled to the Don region at a time when the Zaporozhian Cossacks were quarreling over their lands with Serbian settlers. Vasyl' Kutsenko could have visited the Cossacks' fishing enterprises looking for employment ... there learning stories about the imaginary rights of the Cossacks... [Kulish: 155]

Hence, because no such inscription existed, the collector most likely viewed this episode as "fantasy" with no historical value. At the same time, Kulish asks himself a correct question about the informant, Klym Belik's motivation for telling that particular story, though his explanation appears only partially satisfactory. He explains it by saying that the Cossacks influenced the informant with their stories, which seems plausible. However, the collector does not provide enough information about Belik, his views and contacts to further substantiate that explanation. In general, Kulish made notes conveying his thoughts about the connection between a particular narrative and "actual" history in other passages as well [Kulish: 75, 96,155].

According to the contemporary Ukrainian folklorist, Vasyl' Sokil, Panteleimon Kulish was in the forefront of collecting Ukrainian folk legends and was employing certain standard techniques and approaches. Kulish recorded folk texts using stenography during the actual performance, preserving every single pattern of original speech. Such an approach make those texts priceless to philologists as well as to folklorists [Sokil: 7]. At the same time, Kulish often lacked consistency in providing information on many of his informants and the circumstances, under which the performance or collection took place.

From the available sources it becomes obvious that Kulish's primary interest in oral tradition was its relevance to history. Therefore, to him folklore was just another historical source, though not always an 
accurate one. Such an attitude might have influenced Kulish to record folklore selectively, ignoring texts of "low" historical value. At the same time, the scholar did try to record texts precisely, sometimes asking an informant to repeat his story several times. Though critical of some of his collected texts because of their "fantastic" elements, he nonetheless found certain of them valuable enough to warrant publication. Panteleimon Kulish must have viewed those texts as significant because they provided an insight into the mentality of the Ukrainian folk. This mentality fascinated Kulish, along with many of his contemporaries, though did not turn him into a romantic about folklore.

Since the mid-1800s, collectors of Ukrainian folklore have gradually made advances in their approach to collecting and recording folklore and information about its bearers. In particular, they have developed programs, methodological principles and approaches, aimed at improving the quality of the material collected. In 1854, Mykola Bilozers'ky developed and published the first manual of requirements for collecting Ukrainian folklore [Sokil: 7]. In 1873, a south-western branch of the Russian Geographical Society was founded in Kyiv, thanks to the efforts of Ukrainian scholars and cultural activists such as Volodymyr Antonovych, Mykhailo Drahomanov and Pavlo Chubyns'ky [Sokil: 7]. In 1876, the society published a collection of Ukrainian folk prose (Mykhailo Drahomanov's Malorusskie narodnye predaniia i razskazy (Folk legends and stories of Little Rus')), which was among the bestorganized and fullest collections of folk prose of that time. It included recordings by leading Ukrainian folklorists: Iakiv Novyts'ky, Volodymyr Menchits, Stepan Rudans'ky and Andriy Demins'ky. Drahomanov in particular was interested in the authenticity of texts as well as in providing detailed information about informants and the geographical distribution of their texts [Sokil: 7].

During the 1880s-1890s, the collection and publication of folklore in South-Eastern Ukraine boomed under the auspices of the HistoricalPhilological society of Kharkiv. Among the society's most active members were Iakiv Novyts'ky and Dmytro Iavornyts'ky, who authored the most extensive and interesting collections of folk legends about the Ukrainian Cossacks [Sokil: 7-8].

Though not a trained scholar, Iakiv Novyts'ky (1847-1925) emerged as an important researcher of the Cossack past and a celebrated author of some forty works in the fields of history, ethnography, folklore, statistics, and nature studies. In spite of the fact that he divided his time between teaching, supervising public schools and scholarship, Novyts'ky 
assembled rich collections of folklore [Novitskii 1885, 1894]. Novyts'ky was specifically interested in folk memory about the past of Southern Ukraine, with the Cossacks representing a large part of it. Most legends about the Cossacks were collected by Novyts'ky between 1874 and 1885 and came from the former Cossack lands in the lower Dnipro region (contemporary Zaporizhzhia and Dnipropetrovs'k regions). They deal with the origin of the Cossacks and the foundation of their order, their supernatural characteristics, their land, liberties, wars against the Turks and their disbandment by Empress Catherine II. Novyts'ky also collected many legends about Cossacks and their enchanted buried treasure.

Some of Novyts'ky's recordings were first published in Mykhailo Drahomanov's Malorusskie narodnye predaniia i rasskazy (1876). However, many of the narratives about the Cossacks remained unpublished during Novyts'ky's lifetime. Some of those texts became available to the general public only at the end of the twentieth century in Lehendy ta perekazy (Legends and stories) (1985), Narodna pam'iat' pro kozatstvo (Cossacks in the folk memory) (1991) and Ostrov Khortitsa na Dnepre, ego priroda, istoriia, drevnosti (The island of Khortytsia on the River Dnipro, its nature, history, antiquities) (1997).(3)

Novyts'ky wrote that he spent more than thirty years surrounded by the bearers of historical tradition, in a circle of naturally talented singers, men who cooked, sniffed and smoked tobacco while telling their stories [Novyts'ky 1997 (early 1900s): 4]. "By now, those old men lie in their graves, but their memory is still fresh, and many poetic pictures were preserved by that memory!" [Novyts'ky: 4]. It is likely that Novyts'ky's romantic perception of the past and of Cossacks in particular affected the choice of folklore material he collected and published.

Iakiv Novyts'ky had a permanent country house (kurin') on the island of Khortytsia in the River Dnipro - the heartland of the old Cossack land - where he spent many days and nights talking to people and taking notes [Novyts'ky: 4]. He himself described the typical recording situation: "By day, beneath the shadows of cliffs and pussywillows, at night under a sky full of stars, around the burning bonfire, surrounded by gray-haired old men with tanned faces - those were the circumstances under which our conversations took place" [Novyts'ky: 4]. Dmytro Iavornyts'ky, whose views and contribution will be discussed shortly, describes how Novyts'ky was recognized by one of his old informants during one of their joint expeditions near the town of Oleksandrivsk and Khortytsia: "You are Iakiv Pavlovych, aren't you? I didn't recognize you right away:an old man's memory, you see. You 
would like to ask me about the old times, wouldn't you?" [Evarnitskii 1995 (1888): 139]. Iakiv Novyts'ky had been collecting folklore material in that specific area for a long time, so that he had become well-known for his interest in antiquity. The scholar was particularly interested in talking to elderly people because they remembered the Cossack past. Most likely, he had a group of favorite informants, including Dmytro Bykovs'ky, Osyp Shut' and the "old man" Buhaida, who supplied him with the majority of his narratives. His collecting technique involved informal conversations, which probably helped him to relax with his informants and win their trust. The collector seems to have consciously created romantic settings for his conversations with informants, doing this in part for his own self-image and satisfaction.

In at least some cases, Novyts'ky tried to identify the initial source of the story that he heard. One of his informants, the 87-year old Buhaida, often referred to "his grandfather, who himself was a Cossack" [Novyts'ky: 38].This reference demonstrates that Novyts'ky was to some degree concerned with the authenticity of the narratives. His main concern in collecting and publishing folklore, however, was the preservation of memory about ancient times.

Dmytro Iavornyts'ky (1855-1940) was a prominent historian, archeologist, ethnographer and folklorist, and author of over 200 scholarly works. He entered the historical-philological department of Kharkiv University in 1877, graduating in 1881. In 1881-1882, he published his first historical work on the Zaporozhian Cossacks, entitling it Vozniknovenie i ustroistvo Zaporozhskogo kosha (The foundation and structure of the organization of the Zaporozhian Cossacks). The young scholar was reprimanded by his superiors for choosing this topic over the one proposed by the university (it should be borne in mind that the "Cossack theme" was seen by the Russian authorities as displaying separatist tendencies), and his scholarship was taken away [OliinykShubravs'ka: 6-7]. In 1883, Dmytro Iavornyts'ky published one of his first historical-ethnographic works, Zhizn' zaporozhtsev po rasskazu sovremennika-ochevidtsa (The life of the Zaporozhian Cossacks, as narrated by a contemporary) [Oliinyk-Shubravs'ka: 8]. The same year, Iavornyts'ky was elected a member of the Historical-Philological society of Kharkiv, where he worked with other prominent figures in Ukrainian studies: Oleksandr Potebnia, Mykhailo Sumtsov, Dmytro Bahalii and Petro Efymenko. Iavornyts'ky was considered for a postgraduate position at the university, but it never came through because of his "separatist" views. After this, Iavornyts'ky traveled throughout the 
former Cossack lands, collecting folklore and ethnographic material, and publishing it in various newspapers and journals, particularly Kievskaia starina (Kievan antiquity) [Oliinyk-Shubravs'ka: 8].

Between 1883 and 1888 Iavornyts'ky was engaged in correspondence with Iakiv Novyts'ky. In one of his letters from 1883, Iavornyts'ky announced his intention of conducting expeditions throughout the old Cossack lands. He made these trips in 1884 and 1886, publishing his findings, which included folk legends about the Cossacks, in Zaporozh'e v ostatkakh stariny i predaniiakh naroda (Zaporozh'e in antiquities and folk legend) (1888) [Oliinyk-Shubravs'ka: 9-10]. Within a few years after his Zaporozh'e book, Iavornyts'ky had published several more historical works containing additional folklore and ethnographic materials: Ocherki po istorii zaporozhskikh kazakov i Novorossiiskogo kraia (Sketches from the history of the Zaporozhian Cossacks and the "New Russian" land) (1889), Vol'nosti zaporozhskikh kazakov (The autonomy of the Zaporozhian Cossacks) (1890), Ivan Dmitrievich Sirko- slavnyi koshevoi ataman Voiska zaporozhskikh nizovykh kazakov (Ivan Dmitrievich Sirko- the glorious chieftain of the Host of the Cossacks of the Lower Dnipro) (1894), and his key historical work on the Zaporozhian Cossacks Istoriia zaporozhskikh kazakov (The history of the Zaporozhian Cossacks) (1892-1897).

Dmytro Iavornyts'ky's scholarly interests lay specifically with the Zaporozhian Cossacks. Like Novyts'ky, Iavornyts'ky collected material in the former Cossack lands in the lower Dnipro region. However, unlike Novyts'ky, who merely wanted to preserve the memory of ancient times, Iavornyts'ky's incentive for studying folklore was to expand his primary source base for reconstructing Cossack history. He was primarily interested in first-hand accounts (opovidannia):

Iavornyts'ky: Well, old man, you descend from the real Zaporozhians, do you not?

Rossoloda: I descend from the real Zaporozhians and am a Zaporozhian Cossack myself to a certain extent, because when I was baptized, my father poured some gunpowder in the tub; you see,that was done to ensure [a future Cossack's] powers of endurance from early childhood, - there used to be such a custom among the Cossacks [Evarnitskii, pt 2: 246-47].

In Iavornyts'ky's opinion, those accounts contained truthful information about the Cossacks and their organization in the last period of their existence. However, he also collected legends, particularly those about the Cossack Chieftain Ivan Sirko, and about the Cossacks as invincible warriors-sorcerers (kharakternyky) [Lehendy ta perekazy: 189]. 
As mentioned, most of Iavornyts'ky's folk legends about Cossacks were published in his Zaporozh'e $\mathrm{v}$ ostatkakh stariny i predaniiakh naroda (1888). This work, composed in the form of a travel diary in the first person, was sometimes criticized by Iavornyts'ky's contemporaries for its "lyricism" and interest in "folk tales" (that is, fiction or nonhistorical information). Other scholars, including Ukrainian and Russian literary historians and the ethnographers Mykhailo Sumtsov and Aleksandr Pypin, praised Zaporozh'e as a brilliant work. It features many narratives about the Zaporozhian Cossacks, their supernatural abilities, and about Colonel Semen Palii and Hetman Ivan Mazepa, as well as legends about the origin of various local topographical features (such as cliffs, ravines and groves) [Oliinyk-Shubravs'ka: 24-25]. This work also provides its readers with an insight into Iavornyts'ky's approach to collecting folklore material, his objectives and the personalities of his informants.

On the whole, thanks to his professional training, expertise in various fields and his fascination with the topic, Dmytro Iavornyts'ky can be considered the most authoritative Cossack specialist in nineteenth-century Ukraine. In his studies Iavornyts'ky makes reference to archival material, historical works, archeological artifacts and folklore. His main objective in collecting and analyzing these texts was the illumination of the Cossack past by expanding the source base for his research. Interested in finding new facts, Iavornyts'ky actively interviewed older people who were related to the Cossacks or might have remembered them. The scholar corroborated his findings by testing them against other sources such as written chronicles, government documents and personal diaries. His critical approach was balanced by his romantic view of the Cossacks and their role in Ukrainian history.

It becomes clear that the personalities of folklore collectors and their informants profoundly affected the texts they collected. Kulish, Novyts'ky and Iavornyts'ky each underwent different professional training, had somewhat different philosophies, and pursued somewhat different goals. Panteleimon Kulish was interested in collecting folklore about Ukraine's past rather than specifically about the Ukrainian Cossacks. To him, the main value of the folk texts was their relationship to history. He was less interested in non-historical folklore. Kulish tended to perceive folklore texts as examples of faulty historical memory, and sometimes appears dissatisfied with his informants' "fantasizing." 
By contrast, Novyts'ky's main focus was specifically the collecting and publishing of folklore itself. Novyts'ky viewed folklore as a way of preserving memories about the Cossacks. Iavornyts'ky's main goal overlapped with that of the other two men, though his objectives were focused on reconstructing Cossack history. He used folk narratives as one of his valuable sources. All three of these researchers attempted to underpin their findings in folklore with supporting evidence from other fields.

At this point, I should like to concentrate on the relations between collectors and their informants, as well as to assess to what degree the informants influenced the texts they relayed. The informants' memory and personal experiences also shaped the texts they told. Mainly old people, they were selected for their age and for their knowledge of a specific matter- life in the past and the Cossacks. In some cases, their repertoire, attitudes, motivation and willingness to speak to collectors can be established with considerable accuracy. Among the informants were peasants, Cossacks, priests, wandering merchants, fishermen and watchmen.

Kulish's impression of the bearers of oral tradition in his own time was not favorable. He believed that only those who try to collect folklore are capable of appreciating the difficulties inherent in this activity. "You enter the hut and ask the people there to sing a popular song. And their answer will be: are we so drunk that we have to sing?" [Kulish: 100].The author wrote that a singer begging on the road is more likely to perform church school psalms for a romantically-motivated traveler (such as Kulish himself), but reserve the performance of more valuable Cossack (kozats 'ki) and captives' (nevil'nyts 'ki) songs (4) for their close friends. He will not understand what the researcher finds important. When asked about antiquity, the beggar replies: "Sir! How am I supposed to know about antiquity? I am a young person" [Kulish: 100]. Kulish expressed the view that in order to succeed a collector "must have enough time to let people get to know and like you" [Kulish: 100].

While acknowledging the existence in the past of highly-gifted "blind singers," Kulish viewed their contemporary descendants as "shallow" (izmel'chali): "...The blind singers have long ago become shallow and as time passed, the people have lost interest in their songs and dumy... My Kyivan beggar did not know a single historical song, nor a single military or moralistic duma... The beggars of old attracted attention not by emphasizing their pitiful condition, but by the sound and 
content of their songs... Contemporary beggars secure their income by monotonous begging..." [Kulish: 2-3].

Nonetheless, Kulish recorded his first folk legend (narodnoe predanie) from that blind beggar in Kyiv. Despite his earlier disparaging comments, he admitted that some performers had excellent memories, and were "capable of retaining many songs and stories" [Kulish: 1-2]. The repertoire of his Kyivan informant did not initially impress the collector. However, he eventually recorded from him a very interesting legend "about Mykhailyk and the Golden Gates" and another "about the Tatars' captives."(5)

Kulish does not provide any detailed information about his first informant in his publications, calling him simply "my Kyivan beggar." Semen Iurchenko, Kindrat Taranukha and Klym Belik, who told Kulish legends about the Cossacks, are identified by name, but little else [Kulish: 75, 96, 155]. At the same time, Kulish is much more specific about the blind singers, such as Arkhyp Nykonenko and Andriy Shut, from whom he recorded several dumy and songs [Kulish: 7-14, 43-51].

Novyts'ky and Iavornyts'ky were both primarily interested in interviewing elderly men (didy), who supposedly had first-hand knowledge of the ancient Cossacks. One of Iavornyts'ky's informants was Iakiv Lytvyn, aged 108, "one of the oldest men among the elderly in all the lands of former Zaporozhzha..." [Evarnitskii: 42]. Another informant, Ivan Rossoloda, aged 116, had been a Cossack himself [Evarnitskii: 244].

Iavornyts'ky provides an insight into the collecting situation and the reasons why some of his informants were motivated to tell their stories. For instance, he describes Lytvyn as follows: "In the village of Plakhtiivka there lives an ancient (drevnii) man, Iakov Lytvyn[ov], who loves to tell stories about the Zaporozhian Cossacks during his leisure hours..." [Evarnitskii: 41]. Lytvyn must have been flattered by Iavornyts'ky's attention and interest in his narratives. "Unfortunately," Iavornyts'ky notes, "he is an outsider in this area (zakhozhii chelovek)," that is to say, he has no blood ties and/or close relationships with the Cossacks. "If not for this, with his memory, inquisitive nature and old age he would have provided a great deal of truthful and accurate [information] about the life of the Zaporozhian Cossacks..." [Evarnitskii: 42]. This passage clearly indicates the collector's interest in "credible" accounts as well as his preconceptions about who could be considered "truthful," "accurate" and the "most valuable" source of folklore about the Cossacks. 
Unlike the "outsider" Iakov Lytvyn, another of Iavornyts'ky's exceptionally old informants was identified as "the only [living] representative of the fallen Cossack host of Zaporozhzha" [Evarnitskii: 244]. Ivan Rossoloda was reportedly 116 years old at the time of his interview. He was born into a Cossack family in the town of Nikopol', but spent his youth on a Cossack farm (zymivnyk) after his father left the Sich [Evarnitskii: 244-245]. Ivan Rossoloda married the daughter of a nobleman from the Poltava region. His first wife died six years later, leaving him with their daughter, Iryna. At the time of this interview, Iryna was reportedly 80 years old, with children, grandchildren and great-grandchildren of her own, and now living in the Kuban' region, the land of the Black Sea Cossacks [Evarnitskii: 245]. Rossoloda's second marriage was to a peasant girl, by whom he fathered four sons and two daughters. The informant maintained that he remembered the reign of the Empress Catherine who had died in 1796 [Evarnitskii: 245].

"It was Sunday," Iavornyts'ky writes in his book, "when I came to see Ivan Rossoloda. The weather was great. I crossed the yard and went into the garden, where I saw a small hut... I greeted Rossoloda and we exchanged two or three phrases about the weather, after which I began my inquiries into the life of the Zaporozhian Cossacks. Rossoloda, being forewarned about the coming of the "Zaporozhian lord" (such was my name in the village), was happy to answer my questions. I recorded his entire story accurately over several sessions..." [Evarnitskii: 245-246]. The interview took the form of a somewhat informal exchange:

Rossoloda: What are you interested in?

Iavornyts'ky: I need to ask you some questions about the Zaporozhian Cossacks; what kind of people they were, how they lived and where they went, and what memories they left behind?

Rossoloda: $\quad$ That is to say, you are interested in the truth, the true facts?

Iavornyts'ky: $\quad$ Yes, yes, my dear old man, I want to learn the true facts from you. Do you know anything about them?

Rossoloda: Of course, I know about them, because my father was a Zaporozhian Cossack himself.

Iavornyts'ky: Really?!

Rossoloda: Indeed. Initially, he was deputy to the [Cossack] chieftain

Perebiinis...

Iavornyts'ky: Now, tell me, my dear old man, where did the Zaporozhian Cossacks come from?

Rossoloda: Where did they come from? They came from everywhere. This one [came] from here, another - from there. From ten to twenty, from twenty to thirty - till they became a mighty force... [Evarnitskii: 246].

After these initial questions, Iavornyts'ky inquired about the number of warriors in the Cossack host, about their appearance, their skills, behavior during war and peacetime, their lands and about the end of the 
Cossack host during the reign of Catherine II of Russia [Evarnitskii: 247271].

In Zaporozh'e, Iavornyts'ky describes a joint interview conducted by Novyts'ky and himself with the "old man But." Their informant was telling a story about a Cossack sorcerer escaping the Poles by diving into a pail of water and emerging in the river many miles away. At one point the old man became offended. Perhaps, he thought the interviewer had withheld some information from him, or perhaps he suspected that the interviewer had learned this story from other source. As Iavornyts'ky writes, this situation changed the informant's demeanor quite drastically. Only after Iavornyts'ky told the old man that he did not trust books, except for the Holy Scriptures, "trust was restored and we continued talking about the Zaporozhian Cossacks" [Evarnitskii: 141]. The issue of "trust" was considered important by all collectors of folklore: its absence could jeopardize the interview and the content of the recorded material.

When dealing with informants interviewed in the nineteenth century, it is sometimes possible to learn about their views and reasons for telling a particular story, but sometimes we have to make an educated guess. Several examples illustrate this point clearly. Between 1828 and 1831, Archbishop Gabriel (Rosanov) interviewed an old Zaporozhian Cossack, Mykyta Korzh (d. 1835, aged 104). From him he learned a great deal about the Cossacks' organization, way of life and their past. Mykyta Korzh was interviewed on a number of occasions and was most likely motivated to talk out of reverence for the cleric and respect for the Archbishop's interest in his knowledge. He provided many first-hand details about Cossack laws, justice and the capture of the Sich by the Russians in 1775. It seems that Korzh was quite careful in telling his stories, not wanting to misinform. When he was speaking about the origin of the Cossacks, he pointed out that "I cannot positively establish when exactly and at what period the Zaporozhian Host came into being...According to an oral account, passed from my great-grandfather, grandfather and father, I was informed that the Zaporozhian Cossacks in the times of old were known as Khozary" [Rozanov: 1-10].

The fisherman Stephan Shtepa (age 67) was interviewed by Iakiv Novyts'ky in the village of Voznesenka on December 28, 1877. Shtepa told four legends about the hidden treasure of the Cossacks [Novyts'ky 1997: 47-48]. Little is known about Shtepa, except for his profession, age and place of residence. Perhaps he was more willing to talk and share his knowledge because he was being interviewed during the Christmas holidays, and was therefore not being taken away from his fishing 
business. Another of Novyts'ky's informants, the old man Vasyl Nahyrnii (age 95), was interviewed in the town of Oleksandrivsk on December 1, 1884. He spoke about enchanted treasure buried on the island of Khortytsia. Being ninety five years old himself at the time, Nahyrnii nonetheless referred to the authority of "old men" to establish the story's authority and probably to impress the interviewer who had expressed interest in the past [Novyts'ky: 49].

Summarizing this discussion, the following conclusions can be drawn. The comparison of the lives and professional activity of Kulish, Novyts'ky and Iavornyts'ky shows that these scholars became involved in folklore at different stages in the development of the discipline, and this circumstance certainly affected their careers and views. They possessed different social and educational backgrounds and pursued somewhat different objectives. At the same time, they were all interested in Ukrainian folk prose, particularly folk legends about the Ukrainian Cossacks. They collected many original texts, thereby influencing the collection of folklore in the nineteenth and early twentieth centuries. They also left some notes and hints about their approach to research and their techniques, which supply priceless data to contemporary scholars. In general, their activities provide an invaluable insight into the development of folklore studies in Ukraine during the second half of the nineteenth century.

All things considered, despite the frequent paucity of data about the first collectors of Ukrainian folk legends, it is still possible to reconstruct their views, objectives and method with a considerable degree of accuracy. Most of the information comes from the description of their "method" by the collectors themselves and from an analysis of their views, including their prejudices, and a general familiarity with their life histories. As our findings indicate, the personalities of the collectors affected the folklore they recorded. This had to do not only with their views and approaches, but also the ways in which they influenced their informants. As for the latter, each of the informants had a different life experience, motivation and stories to tell. This can be similarly deduced from the texts they told as well as from the notes of the collectors. 


\section{NOTES}

1 Roman I. Shiyan, "Cossack Motifs in Ukrainian Folk Legends" (Ph.D. diss., University of Alberta, 2006), 6-18.

2 Dumy can be described as folk epic recitations. They represent a genre of "Cossack epics which evolved on the basis of Cossack military life." [Kolessa 1983: $118]$.

3 Unfortunately, some of his notes, containing folklore, were confiscated by the authorities in 1878, and have never been recovered.

$4 \quad$ Cossack (kozats'ki) and captives' (nevil'nyts'ki) refer to specific song cycles within the larger body of Ukrainian folk song. Cossack songs deal with the life of the Ukrainian Cossacks in war and peacetime, while captives' songs portray the suffering of imprisoned Ukrainians (Cossacks and others) in Turkish and Tatar captivity.

5 Panteleimon Kulish calls him the "representative of a new generation [of professional beggars]", that is, a person unworthy of his glorious and prolific predecessors [Kulish: 2].

\section{WORKS CITED}

Dei, O. I et al. (eds). 1985. Lehendy ta perekazy [Legends and Stories]. Vol. 1. Kyiv: Naukova dumka.

Doroshenko, Dmytro. 1996. Ohliad ukrains'koi istoriohrafii. Derzhavna shkola: istoriia, politolohiia, pravo [A Survey of Ukrainian Historiography. The Statist School: History, Political Science, Jurisprudence]. Kyiv: Ukrainoznavstvo.

- - 1923. Panteleimon Kulish. Literaturni kharakterystyky ukrajins'kykh pys'mennykiv [Panteleimon Kulish. The Literary Characteristics of Ukrainian Writers]. Vol. 4. Leipzig: Ukrains'ka nakladnia.

Evarnitskii, Dmitrii. 1888. Zaporozh'e v ostatkakh stariny i predaniiakh naroda [Zaporozh'e in Antiquities and Folk legend]. Pts 1, 2. St Petersburg: L. F. Panteleev.

Kolessa, Filiaret. 1983. Ukrajins'ka usna slovesnist' [Ukrainian Oral Literature]. Intro. Mikuláš Mušinka. Edmonton: Canadian Institute of Ukrainian Studies; University of Alberta.

Kulish, Panteleimon. 1856. Zapiski o Iuzhnoi Rusi [Notes about Southern Rus']. Vol. 1. St Petersburg: V tip. Aleksandra Iakobsona.

Novitskii, Iakov. 1885. "Iz narodnykh predanii o zaporozhtsakh" [From the folk stories about the Zaporozhian Cossacks]. Kievskaia starina 10: 350-53.

—_. 1894. "Malorusskiia pesni, preimushchestvenno istoricheskie, sobranye Ia. P. Novitskim v Ekaterinoslavskoi gubernii v 1874-1894 godakh" [The songs of Little Rus', mostly historical, collected by Ia. P. Novitskii in Ekaterinoslav province, 1874-1894]. Sbornik Kharkovskogo istoriko-filologicheskogo obshchestva. Vol. 6. Kharkov: Tip Gub. Pravleniia.

- - 1997. Ostrov Khortitsa na Dnepre, ego priroda, istoriia, drevnosti [The Island of Khortytsia on the Dnipro]. Zaporizhzhia: Tandem-U.

Oliinyk-Shubravs'ka, Mariia (ed.). 1995. "Rannia naukova diial'nist' D. I. Iavornyts'koho ta ioho persha istoryko-narodoznavcha monohrafiia pro Zaporozhzha" [The early scholarly activity of D.I. Iavornyts'ky and his first historical-ethnographic 
monograph about Zaporozhzha]. Zaporozh'e v ostatkakh stariny i predaniiakh naroda. Kyiv: Veselka.

Rozanov (Archbishop Gabriel). 1842. Ustnoe povestvovanie byvshago zaporozhtsa, zhitelia Ekaterinoslavskoi gubernii i uezda, seleniia Mikhailovki, Nikity Leontievicha Korzha [An Oral Account by the Former Cossack Mykyta Korzh]. Odessa: V Gorodskoi tipografii.

Sokil, Vasyl'. 2003. Istorychni perekazy ukraintsiv [Historical Narratives of the Ukrainian people]. L'viv: Vyd. M. Kots'. 